\title{
TWO SIBLINGS WITH LETHAL PNEUMOCOCCAL MENINGITIS IN A FAMILY WITH A MUTATION IN INTERLEUKIN-1 RECEPTOR-ASSOCIATED KINASE 4
}

\author{
Anselm Enders, MD, ${ }^{*}$ Ulrich Pannicke, PhD, ${ }^{*}$ Reinhard Berner, MD, Phillip Henneke, MD, Klaus Radlinger, MD, \\ Klaus Schwarz, MD, and Stephan EHL, MD
}

We describe two siblings with one confirmed and one inferred homozygous base pair deletion in the gene for interleukin1-related kinase 4 (IRAK-4) who died of pneumococeal meningitis at 2 and 14 months, respectively. Interleukin-1-related kinase 4 deficiency is a potentially lethal immunodeficiency characterized by a poor inflammatory response to pyogenic infections. (J Pediatr 2004;145:698-700)

B oth bacterial virulence factors and host factors contribute to susceptibility and outcome of invasive pneumococcal disease. Toll-like receptors are transmembrane proteins that recognize conserved microbial components and constitute a first line of defense that helps protect the host against invasion of colonizing bacteria such as Streptococcus pneumoniae. Interleukin1-related kinase 4 (IRAK-4) links activation of toll-like receptors to translocation of nuclear factor-kappa B (NF- $\kappa \mathrm{B})$ and subsequently the transcription of inflammatory genes. Accordingly, mutations in IRAK-4 have been linked to increased susceptibility to bacterial infection. ${ }^{1,2}$ All four patients with IRAK-4 deficiency as yet described ${ }^{3,4}$ had recurrent but nonlethal infections with pyogenic bacteria, in particular with $S$ pneumoniae. Characteristic findings were reduced inflammatory responses and a transient neutropenia during infections. We describe two siblings with IRAK-4 deficiency who had lethal pneumococcal meningitis.

\section{CASE REPORTS}

Patient 1 was the first child of consanguineous Turkish parents. His mother had 5 spontaneous abortions ascribed to an arcuate uterus. During his first 13 months, the boy had two short hospital stays for bronchitis and gastroenteritis. At 13 months of age, he was admitted with a 4-day history of refusal to walk. He was afebrile. Erythrocyte sedimentation rate was $68 \mathrm{~mm}$, C-reactive protein (CRP) was $25 \mathrm{mg} / \mathrm{L}$, and leukocyte count was $9100 / \mathrm{mm}^{3}$ (neutrophils, $1820 / \mathrm{mm}^{3}$ ). Cefotaxime was given for suspected septic arthritis/osteomyelitis of the left hip joint. In two blood cultures, Streptococcus parasanguis was isolated. During the hospital stay, the boy's maximal temperature was $38.9^{\circ} \mathrm{C}$; CRP rose to $61 \mathrm{mg} / \mathrm{L}$, and maximal leukocyte count was $16,300 / \mathrm{mm}^{3}$. He was discharged after 3 weeks of intravenous antibiotic therapy.

Five weeks later, the boy was readmitted after a night of recurrent vomiting. He was unwell but still alert; his temperature was $38.3^{\circ} \mathrm{C}$. CRP was $34 \mathrm{mg} / \mathrm{L}$ and leukocyte count was $2600 / \mathrm{mm}^{3}$ (neutrophils, $1240 / \mathrm{mm}^{3}$ ). Four hours after admission, he had two generalized seizures. Analysis of the cerebrospinal fluid (CSF) revealed 11 cells $/ \mathrm{mm}^{3}$ with undetectable glucose, CSF protein of $621 \mathrm{mg} / \mathrm{dL}$, and a lactate level of $9.8 \mathrm{mmol} / \mathrm{L}$. Microscopy revealed numerous Gram-positive diplococci. An antigen test for $S$ pneumoniae was positive. Bacterial cultures of blood and CSF were negative. After treatment with cefotaxime, the patient had cardiorespiratory failure with subsequent refractory cardiac arrest and died 8 hours after admission.

\begin{tabular}{llll}
\hline CRP & C-reactive protein & IRAK-4 & Interleukin-I receptor-associated kinase \\
CSF & Cerebrospinal fluid & NF-kB & Nuclear factor-kappa B \\
& & \\
\hline
\end{tabular}

From The Center for Pediatrics and Adolescent Medicine, University of Freiburg, Freiburg, Germany; The Institute for Clinical Transfusion Medicine and Immunogenetics UIm and Department of Transfusion Medicine, University of Ulm, Ulm, Germany; and The Children's Hospital Lörrach, Lörrach, Germany.

Supported by the SFB 620 (Project A4).

* Drs Enders and Pannicke contributed equally to this work.

Submitted for publication Mar 18, 2004; last revision received May 19 , 2004; accepted Jun 28, 2004.

Reprint requests: Dr Stephen Ehl, Center for Pediatrics and Adolescent Medicine, University of Freiburg, Mathildenstrassel, D-79106 Freiburg, Germany. E-mail: ehl@kikli.ukl.unifreiburg.de.

0022-3476/\$ - see front matter

Copyright (C) 2004 Elsevier Inc. All rights reserved.

10.1016/j.jpeds.2004.06.065 
Patient 2 was the fourth child of the same family. At 2 months of age, the girl presented with unilateral cervical lymphadenopathy. She was afebrile and well-appearing and was treated with oral cefaclor. During the same night, she vomited once, appeared increasingly sick, and had development of dyspnea. On admittance she appeared toxic, with a raised fontanelle, dyspnea, and irritability. Her temperature was $37.5^{\circ}$ C. The leukocyte count was $4200 / \mathrm{mm}^{3}$ (neutrophils, $1760 / \mathrm{mm}^{3}$ ), with a ratio of immature/total cells of 0.7 . CRP was $69.9 \mathrm{mg} / \mathrm{L}$. Analysis of CSF revealed $133 \mathrm{cells} / \mathrm{mm}^{3}$ with undetectable glucose, a protein level of 25 $\mathrm{mg} / \mathrm{dL}$, and lactate values of $11.9 \mathrm{mmol} / \mathrm{L}$. Therapy was initiated with ampicillin, tobramycin, and ceftazidime. Subsequently, S pneumoniae was isolated from both blood and CSF cultures. A few hours later, the girl required cardiopulmonary resuscitation. Refractory brain edema developed, and she died 16 days after admission. Her maximal temperature was $38.0^{\circ} \mathrm{C}$; maximal $\mathrm{CRP}$ was $92 \mathrm{mg} / \mathrm{L}$, and maximal leukocyte count was $22.300 / \mathrm{mm}^{3}$.

The finding of recurrent invasive infections with Streptococcus spp in two children of consanguineous parents associated with a poor inflammatory response suggested a genetic deficiency in NF- $\mathrm{KB}$-mediated immunity such as IRAK-4 deficiency. Sequencing of genomic DNA from patient 2 revealed a homozygous single base pair deletion in exon 5 of the IRAK-4 gene (Figure, $A$ ) leading to a premature stop signal 30 codons downstream. Because no material was available for further analysis, it remains open whether no IRAK-4 protein or a truncated protein lacking the serine/ threonine kinase domain was expressed. The clinical phenotype of patient 1 suggests that this child was also homozygous for the deletion. Both parents and one sibling were heterozygous and clinically healthy (Figure, $B$ ).

\section{DISCUSSION}

Host factors that limit infection with $S$ pneumoniae include (1) molecules and signaling pathways involved in bacterial recognition and activation of macrophages and neutrophils, ${ }^{1}$ (2) CD27+ IgM+ memory B cells mediating early antibody responses against polysaccharides, ${ }^{5}(3)$ an intact spleen required as a filter for pathogens and for differentiation and maintenance of IgM+ memory B-lymphocytes, ${ }^{5,6}$ (4) T-lymphocytes providing help for mature, germinal-centerdependent B-lymphocyte responses, (5) B-lymphocyteproducing antibodies, in particular of the IgG2 subclass, ${ }^{7}$ and (6) complement factors, mainly $\mathrm{C} 2-\mathrm{C} 4 .{ }^{8}$

Four IRAK-4-deficient patients have been described. ${ }^{3,4}$ All had recurrent infections mainly with Staphylococcus aureus and $S$ pneumoniae. Two had pneumococcal meningitis, one at 9 and 20 months, the other at 6 months of age. Other infections included septic arthritis, osteomyelitis, pneumonia, cellulitis, cutaneous and intra-abdominal abscesses, endophthalmitis, gangrene of the leg, and sinusitis. Problems with viral, fungal, or mycobacterial infections were not described. Our report confirms this phenotype and emphasizes that IRAK-4 deficiency may be a life-threatening disease.
Wildtype Exon 5:

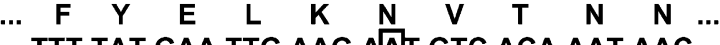 ... TTT TAT GAA TTG AAG AAT GTC ACA AAT AAC ...}

\section{Deletion Exon 5 (A 573 del):}

\section{$\begin{array}{llllllllllllllllll}\ldots & \mathbf{F} & \mathbf{Y} & \mathbf{E} & \mathbf{L} & \mathbf{K} & M & S & \mathbf{Q} & \boldsymbol{l} & T & \ldots\end{array}$ ... TTT TAT GAA TTG AAG ATG TCA CAA ATA ACT ...}

B

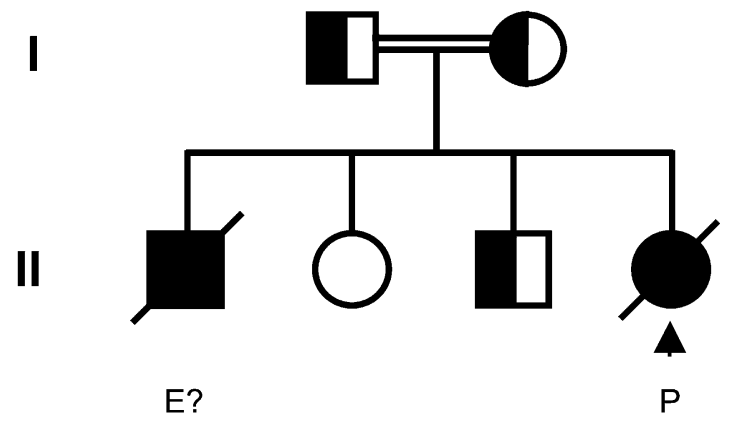

Figure. Genetic analysis of IRAK-4 deficiency. A, Part of the wildtype nucleotide as well as the protein sequence of IRAK-4 exon 5 are depicted. The nucleotide deleted in the IRAK-4 deficiency described (A573del in GenBank Submission NM_016123) is boxed. The consequences of this single nucleotide deletion are shown. B, Pedigree of the family with mutations in IRAK-4. E, Evaluation unknown; $P$, proband.

Reduced inflammatory responses and neutropenia during infections were characteristic for all IRAK-4-deficient patients. ${ }^{3,4,9,10}$ The acute phase and CSF inflammatory reactions of our two IRAK-4-deficient patients were lower than in most children with pneumococcal meningitis. Neutropenia, low CSF glucose, high CSF protein, and low CSF cell counts are associated with high mortality rates in pneumococcal meningitis. ${ }^{11}$

Why was the meningitis lethal in our patients, whereas all 4 reported IRAK-4-deficient children survived and presently appear healthy? It is unlikely that the particular genotype was responsible for the lethal phenotype because all previously described mutations were also located in the kinase domain. ${ }^{3,4}$ Alternatively, it is conceivable that IRAK-4 signaling is particularly limiting for antimicrobial defense within the first years of life. If during that time high-risk infections are survived, the recurrent exposure to pathogens may build up sufficient B-lymphocyte memory to control infections in the absence of IRAK-4. Consequences for treatment of identified patients would be early pneumococcal vaccination, antibiotic prophylaxis, and early and aggressive treatment of bacterial infections with high awareness that febrile and inflammatory reactions may be minimal. One patient with IRAK-4 deficiency, who showed failure to sustain antibody response to polysaccharide and protein antigens, had apparent benefit from monthly intravenous immunoglobulin therapy. ${ }^{12}$ 
We thank Matthias Brandis for continuous support. We appreciate the technical help of Sylvia Braun and Ingrid Janz.

\section{REFERENCES}

1. Puel A, Picard C, Ku CL, Smahi A, Casanova JL. Inherited disorders of NF-kappaB-mediated immunity in man. Curr Opin Immunol 2004;16: 34-41.

2. Picard C, Puel A, Bustamante J, Ku CL, Casanova JL, Bonnet M, et al. Primary immunodeficiencies associated with pneumococcal disease. Curr Opin Allergy Clin Immunol 2003;3:451-9.

3. Picard C, Puel A, Bonnet M, Ku CL, Bustamante J, Yang K, et al. Pyogenic bacterial infections in humans with IRAK-4 deficiency. Science 2003;299:2076-9.

4. Medvedev AE, Lentschat A, Kuhns DB, Blanco JC, Salkowski C, Zhang $\mathrm{S}$, et al. Distinct mutations in IRAK-4 confer hyporesponsiveness to lipopolysaccharide and interleukin-1 in a patient with recurrent bacterial infections. J Exp Med 2003;198:521-31.

5. Kruetzmann S, Rosado MM, Weber H, Germing U, Tournilhac O, Peter $\mathrm{HH}$, et al. Human immunoglobulin M memory B cells controlling Streptococcus pneumoniae infections are generated in the spleen. J Exp Med 2003;197:939-45.
6. Gilbert B, Menetrey C, Belin V, Brosset P, de Lumley L, Fisher A. Familial isolated congenital asplenia: a rare, frequently hereditary dominant condition, often detected too late as a cause of overwhelming pneumococcal sepsis: report of a new case and review of 31 others. Eur J Pediatr 2002;161: 368-72.

7. Shackelford PG, Granoff DM, Polmar SH, Scott MG, Goskowicz MC, Madassery JV, et al. Subnormal serum concentrations of IgG2 in children with frequent infections associated with varied patterns of immunologic dysfunction. J Pediatr 1990;116:529-38.

8. Figueroa JE, Densen P. Infectious diseases associated with complement deficiencies. Clin Microbiol Rev 1991;4:359-95.

9. Kuhns DB, Long Priel DA, Gallin JI. Endotoxin and IL-1 hyporesponsiveness in a patient with recurrent bacterial infections. J Immunol 1997;158:3959-64.

10. Haraguchi S, Day NK, Nelson RP Jr, Emmanuel P, Duplantier JE, Christodoulou CS, et al. Interleukin 12 deficiency associated with recurrent infections. Proc Natl Acad Sci U S A 1998;95:13125-9.

11. Kornelisse RF, Westerbeek CM, Spoor AB, van der Heijde B, Spanjaard L, Neijens HJ, et al. Pneumococcal meningitis in children: prognostic indicators and outcome. Clin Infect Dis 1995;21:1390-7.

12. Day N, Tangsnmankong N, Ochs H, Rucker R, Picard C, Casanova $\mathrm{J}-\mathrm{L}$, et al. Interleukin receptor-associated kinase (IRAK-4) deficiency associated with bacterial infections and failure to sustain antibody responses. J Pediatr 2004;144:524-6. 